\title{
FLOATING HOUSE TECTONICS ON LAKE TEMPE: BETWEEN TRADITION AND RESILIENCE
}

\author{
Naidah Naing \\ Department of Architecture, Indonesian Muslim University \\ Indonesia \\ e-mail: naidah.naing@umi.ac.id
}

\begin{abstract}
The tectonic knowledge of the people who live in floating houses comes from the knowledge of the tradition of building land on stilt houses because the fishing communities who live in floating houses also live on land. However, the climatic conditions above the water are extreme and different from the land, causing the tectonics of the floating house to adapt to the climatic conditions on the water so that the floating house has resistance to natural disasters on the water. The problem of this research is that there is a change in the tradition of building from traditional mainland stilt houses to floating houses, thus creating a unique tectonic expression in floating houses. The purpose of this study is to reveal the tectonics offloating houses based on the tradition of building and surviving on the water. Research method used in this study is a qualitative method with an ethno-architecture approach. The results showed that the tectonics of the floating house originating from the mainland stilt house tradition underwent changes in several parts, especially in the lower and middle structures. However, it does not change the concept of Bugis society's cosmology. The formation of floating house tectonics is influenced by extreme climatic factors so that for the resilience of houses on water a structural system is needed that can anticipate climatic conditions.
\end{abstract}

Keywords: tectonic, floating house, tradition, disaster resilience

\section{INTRODUCTION}

Tectonics is closely related to materials, structures, and constructions, but tectonics emphasizes the aesthetic aspects produced by a structural system or expression of a construction rather than the technological aspects. So that tectonics can be interpreted as processing connection systems in construction so as to increase the expression of buildings using artistic values (Juniwati et al., 2003). Tectonics in the floating house on Lake Tempe is a form of expression of a house structure panggung masted low coupled with a raft structure so that the incorporation of this structure has created a unique tectonic. 
Floating houses on Lake Tempe are inhabited by Bugis fishing communities who come from the mainland around the lake (Naing, Santosa, \& Soemarno, 2011). This fisherman chooses to live on the water because of his dependence on water as a place to earn a living. The tradition of building houses brought from the mainland causes floating houses to be built with the concept of a traditional house on stilts, although with a different shape. Some parts of the structure of the house on stilts are different from the floating house, especially the pillars under the tall houses turn into low pillars. The lower structure using stone in a traditional stilt house turned into a raft construction of bamboo material. The overall structural form of the low-pole stilt house tied on a bamboo raft creates a unique structural and aesthetic composition, so that many tourists and scientists are interested in traveling in the floating house. This is in line with what Adolf Heinrich Borbein stated in 1982 (Frampton, 1995) in his Philology study which said that tectonics became the art of meeting or connection. Tectonics The floating house is a form of expression of a traditional stilt house structure that has undergone changes in shape and size.

Actually, the expression of the floating house shape wants to embody and pass on the cultural tradition of building a mainland Bugis house on stilts, by making a low-pole stilt house. Where according to Mardanas (1985) in Rahmansah (2014) that the Makassar Bugis adhere to the belief attau riolong which teaches a cosmological view, that the universe (macro cosmos) is composed of three levels, namely: botting langi' (upper world), ale kawa (middle world) and uri liyu (under world). So that the cosmological view of the macro cosmos is manifested in his home which is considered a micro cosmos. Therefore, the house consists of three parts, namely: rakkeang (paraparal attic), ale bola (body of the house) and awa bola (under the house). The three parts are centered on the posi bola, which is the part that is considered sacred.

In addition, the traditional home according to Saliya (Saliya, 2003) in (Rahmansah \& Rauf, 2014), traditional architecture basically knows no formal measure as meters or feet. The size used is always concrete, which refers to the size or magnitude of the object, for example, the size of a part of the human body, such as fathoms, cubits, shoulder height, upright spans, and step width. These quantities are always associated with cosmological values that view everything in terms of the position of the universe or the universe which is part of the process of creating the universe. This is in line with Ronald (2005) that the unit of measure used to determine the amount of length or distance is used body parts starting from the thumb, palms, soles of feet, and arm length or better known as anthropometric measurements. In floating house tectonics, it is interesting to investigate whether the size of the structure used in the floating house is still concrete based on the size of the human body or there are other considerations.

In addition, floating houses are always faced with extreme conditions on the water, such as strong winds and rising water levels during the rainy season. Therefore, a strong and flexible house structure is needed against strong winds and water waves, so that the house can have resilience in order to survive on the water. The use of houses on stilts with low-masted structures is a strategy in anticipating strong winds so that the floating house is not overturned by strong winds. Low-masted structures have been used by fishing communities in the tradition of building floating houses for decades (Naing \& Iskandar, 2015). 
The problem of this research is that there is a change in the tradition of building from traditional mainland stilt houses to floating houses, thus creating different tectonic expressions. The expression created has deviated from the early tradition of building a mainland house on stilts. In addition, the extreme climate on the water makes the community creative in creating an overall house structure system that can anticipate disasters so that they can survive living on water. Whereas traditional architecture as a form of cultural heritage is the deposition of a phenomenon from time to time that takes place in an evolutionary sequence with a cultural situation full of conflict, change, or development (Budiharjo, 1989) in (Rahmansah \& Rauf, 2014). This is in line with research conducted by (Meutia, 2017) that traditional Acehnese houses have structural advantages in responding to earthquakes. Similarly, research (Kamurahan, 2018) that the model of the structure and construction of the Jaton community stilt houses applies the principles of earthquake-resistant buildings, which are viewed from the shape of the floor plan, frame structure and roof structure. So, the purpose of this study is to reveal the tectonic form of floating houses based on building traditions in relation to resilience in anticipating disaster on water.

The tectonic expression of the floating house is a legacy of the tradition of building traditional mainland stilt houses that have undergone a transformation process, both in size, function, and structure. But on the other hand, the location of the floating house on the water demands a strong structural system in order to have resilience in anticipating the extreme climate on the water. The expression of tradition and the expression of the survival of the settlers have created a tectonic expression in the floating house that is interesting to study.

\section{THEORY AND RESEARCH METHOD}

\section{THEORY}

Porphyrios in an essay entitled From Techne To Tectonics (Ballantyne, 2002), describes tectonics as a method and technique of processing building materials that requires expertise and skills in realizing an expressive and impressive formation. The term tectonic was also introduced by Eko A. Prawoto, that tectonics is an architectural aspect related to how to process and bring together building materials and to articulate the completion of the connection in relation to the construction style (Mahatmanto, 1999 in Rembulan et al., 2014).

Based on an etymological understanding, tectonics comes from the Greek, from the word tekton which means carpenter or builder, or also refers to the verb tektainomai which means craft or craftsmanship and the meaning of the art of using an axe. This term first appeared in the Sappho language, where tekton is a carpenter who plays a role in the elements of his art, so tectonics concerns the manufacturing process that includes poetic ideas associated with machines, tools, technology and manufacture, material formation. Philosophically, according to Thomas Aquinas, beauty radiates truth or in other words, tectonics is the art of construction (Frampton 1995). 
Tectonics in architecture is an engineering and material processing method in a system of construction that requires an expertise and skill in creating a shape that is expressive and aesthetic. From this understanding, there are several terms, including: a) Structural system is an organizational form of structural elements intended to distribute loads characteristically; b) The construction system is the way in which the structure of the building is implemented (strength issues, connections per element/section connected in detail); c) Expression from the origin of the word to express which means to state, a thought; expression means expression, facial expression. So expression in the context of architecture has a meaning as an expression/display of the face/architectural form that is embodied by its constituent elements (Oktawati \& Sahabuddin, 2016).

Tectonics in architecture is a creation that strives for the structure and construction of buildings not only to play a role in the robustness of the building but more than that how to express the beauty contained therein and aspects of creative craftsmanship skills according to the needs and potential of the environment at the object location. To answer the challenges of tropical architecture, tectonics is very likely to provide solutions to sustainable architectural solutions (Priyomarsono and Surya, 2016).

According to Porphyrios in tectonics, there are 3 main things that are the main business (Ballantyne, 2002) in (Oktawati \& Sahabuddin, 2016) namely:

a) Material properties

Material properties consist of limited properties and formal properties of construction materials. The limited nature of the material in question concerns the ability of the material to be used as a construction material, for example, strength, durability, and ease of obtaining it. While the intended formal properties concern the ability of the material to withstand the force or load imposed on it (compressive strength or tensile strength). By paying attention to the properties of this material will greatly affect its placement in the raised. Therefore, the material and its properties are very significant in tectonics.

b) Methods and techniques of combining materials

Method refers to the method used, while combining technique refers to the process of preparing materials. The position of methods and techniques of combining materials occupies the most important place in tectonics, because tectonics is basically a way of completing construction. Method refers to the way of splicing and technique refers to the strategy or work process used. For example, merging two pieces of paper, the method used is to glue the two papers with the technique of gluing part or all of the paper.

c) Visual statics of form

Visual statics of form in question are the principles of statics (science of style) that can be displayed by formation, through construction activities. This element refers to the appearance that is produced through the construction process, where the form that is present appears with a face that depicts material relations in an ontological, unified, balanced, and expressive manner. Thus, if you pay attention to this element, it is believed that the formations present can reveal the existence of the form, state an intention and give identity to the form itself. 
Semper divides tectonics into two, namely technical (ontological) and symbolic (representational) (Frampton, 1995). With a focus on producing architectural elements, Semper also divides buildings into tectonic and stereotomy crafts. Tectonics are linearly light component frame constructions, and stereotomy are mass and volume components. Stereotomic, stacking and arranging heavy load elements such as bricks because the word comes from the Greek with 'stereo' which means 'solid' and 'Tomia' which means 'to cut' (Frampton, 1995). Based on the understanding of formation, presenting tectonics in assembling and assembling buildings proposed by Semper confirms the classification of buildings (architecture) with 2 (two) procedures that underlie the assembly process, namely (first) tectonics which is a lightweight framework consisting of linear components forming a spatial matrix or can be said to be the development of constructions and structures used to form spaces; and (all two) stages stereotomy which forms part of the basis on which the mass and volume of space formed from the elements-heavy elements, such as processing link systems to the construction and structure that will enhance the expression of the building by presenting artistic value (Frampton, 1995 in Sir, 2015).

\section{RESEARCH METHOD}

\section{Kinds/ Nature of Research}

From the tectonic theory mentioned above, it can be concluded that tectonics is structure, construction, aesthetics, material expression, and craftsmanship. Where this theory indicates all tectonic elements based on knowledge and experience of building houses by the community according to natural conditions. This research is descriptive qualitative because the research is carried out in natural conditions or carried out on natural objects, because the research location is in the floating settlements of Lake Tempe. The characteristics of this research location are that it is located between three districts in South Sulawesi-Indonesia, namely Wajo, Soppeng and Sidenreng Rappang districts. However, the largest area of Tempe Lake is in Wajo Regency, so the research location is in Wajo Regency. The characteristics of Tempe Lake, which is shaped like a cup, experience ups and downs based on seasonal conditions. If the dry season, the volume of lake water is getting lower and lower to the middle so that the floating house will be moved to the middle of the lake. Meanwhile, during the rainy season where the volume of water will continue to increase, causing the lake water to overflow to the mainland, so that the floating house will be moved to the edge of the lake closer to the mainland. There are 115 floating houses in the research location. However, due to the procedures for building houses with almost the same structure and construction, this study only took one house sample for tectonic research. The following Figure number one shows the research location.

The architectural approach explains the physical condition of the floating house structure, building techniques, how to connect each part of the structure and the construction of the floating house. While the ethnographic approach explains the system of traditions, culture, values, norms and rules and beliefs used by the community in building floating house structures (Spradley 2006). The combination of 
these two approaches is expected to produce ethno-architectural research, so that the results of this study are not only in the form of artifacts (the tectonic traces of floating houses) but deeper into exploring the meaning of floating house tectonics between maintaining building traditions and the strength of resilience in anticipating extreme disasters in the water. The researcher himself is the key figure in making observations. Meanwhile, in-depth interviews were conducted with residents of floating houses (fishermen), panre bola (home builder), macoa tappareng (traditional leaders) and community leaders who are considered to understand the history, philosophy and rules of living on water.
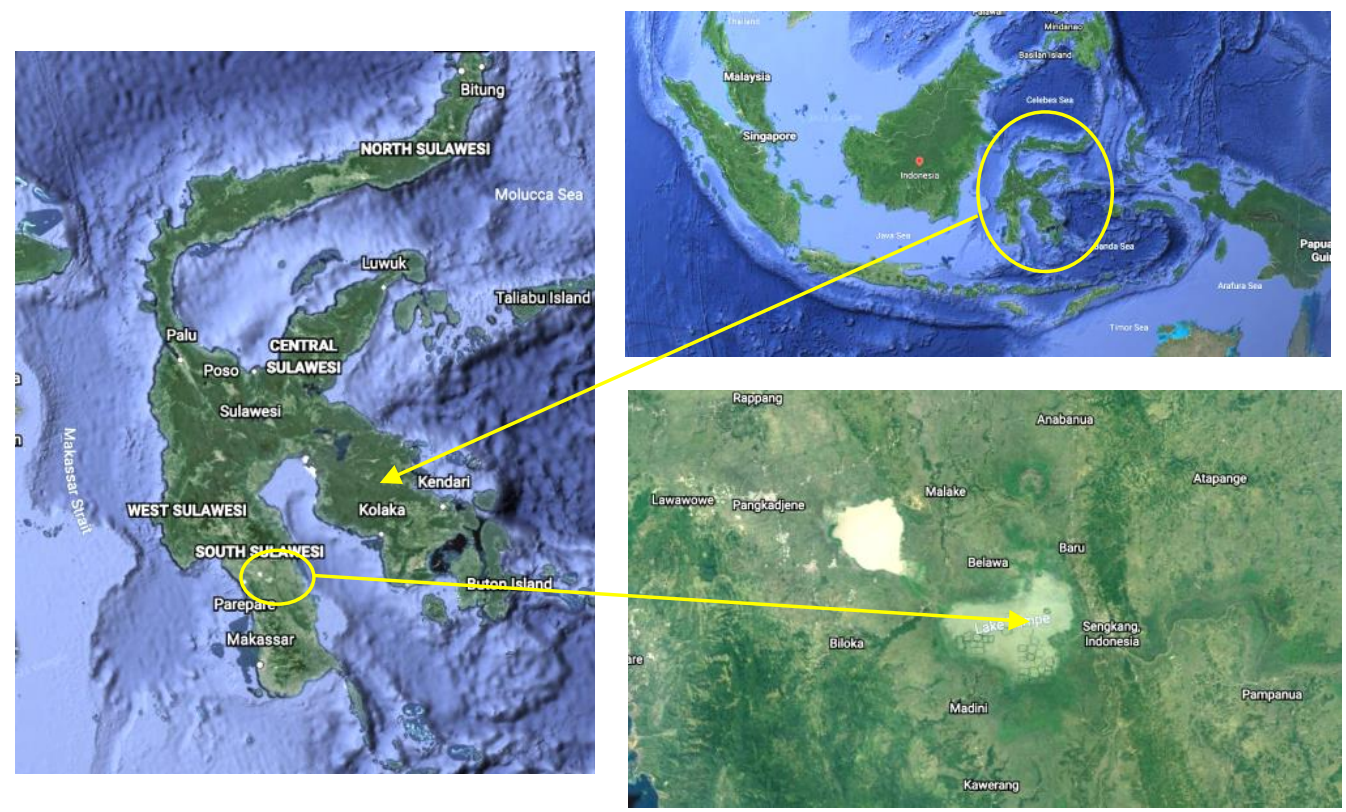

Figure 1. Research Location Map Sources: Google Earth, 2021

\section{Sources and Data Collection Techniques}

Sources of data in this study were obtained by using primary and secondary data. Furthermore, data collection methods or techniques are participant observation, indepth interviews, and documentation studies. Participant observation by observing the structure of the floating house, the construction and materials used, as well as the aesthetics of the construction details and the overall structure. Meanwhile, in-depth interviews were conducted with housebuilders (in the local Bugis language called Panre Bola), related to the construction used in floating houses, including the connection system in the main structure of the house, the function of the construction system, the materials used, the size of the material, how to arrange the construction used. creating the expression of a floating house, and a knowledge system or craftsman's expertise in building a floating house. 


\section{Analysis Method}

Data analysis is more focused during the process in the field along with data collection in a certain period. At the time of observation in the field, an analysis has been carried out. Likewise, at the time of the interview, an analysis of the interview answers was carried out. After being analysed, it felt unsatisfactory, then continued with more questions, until a certain stage, data that was considered credible was obtained. In this study, the data analysis of the Spradley Model (1980) was used because the activities in qualitative data analysis were carried out interactively, from the broad and then focused on the analysis phase starting from the analysis of domains, taxonomies, componential and cultural themes. In addition, this analytical model is suitable for use with architectural and ethnographic approaches, which can find a structural reinforcement system model based on local wisdom for disaster mitigation on water.

\section{Research Stages}

According to Spradley (1980) divides data analysis in qualitative research based on the stages in qualitative research. The qualitative research process after entering the field, begins with determining a key informant who is a reliable informant, who is able to open the door to enter the object of research (informants in this study consisted of residents of floating houses, and panre bola (builders of floating houses). Interviews were conducted with the informants and recorded the results of the interviews. After that, attention was paid to the object of research and began to ask descriptive questions related to the structural and construction systems used in floating houses, the functions and materials used to fulfil the aesthetic and strength functions.

Furthermore, an analysis of the results of the interviews was carried out. Based on the results of the interview analysis, domain analysis was then carried out, namely the researchers' efforts to obtain a general description of the floating house structure data, so that the researchers knew the domain or domain of the house structure data that had been determined according to the focus of house construction, materials, and expressions of floating house structures. The next step is to carry out taxonomy analysis to understand certain domains in more detail according to the focus of the problem such as connection systems, connection techniques, etc. Taxonomic analysis was carried out organizing/collecting elements that are similar in a domain. This was obtained by conducting in-depth observations and interviews related to the floating house structure. Based on the taxonomic analysis, a contrast question was then asked, followed by a componential analysis. The results of the componential analysis, then found cultural themes in floating house tectonics. These findings are then written in an ethno-architectural research report. 


\section{RESULTS AND DISCUSSION}

\section{Floating House Tectonics Based on Building Tradition}

The definition of a floating house is a house with a construction system that is not attached to the ground surface, but rests on a floating system on the water. This system is widely used in housing built in water areas, such as fishing settlements. The fishing community of Lake Tempe and the surrounding community used to call the house on this raft as bola mawang (bola = house and mawang = floating or floating), so it is commonly called a floating house. Floating houses then and now are not much different. Both the model, form and function.

From the results of taxonomic analysis, floating houses have similarities with stilt houses on land where their construction is related to the philosophical values adopted by the Bugis, namely assuming that the universe (macro cosmos) is composed of three, namely uri liu (underworld), ale kawa (middle world) and botting langi (upper world). This view is manifested in the building of houses which are seen as micro cosmos. Therefore, the floating house is divided into three vertical structures, namely: (1) awa bola (bottom = between the floor of the house and the raft); (2) ale bola (house body) which is a living room and, (3) rakkeang (roof), so that it is a house on stilts (Mardanas, 1985) in (Naing \& Halim, 2013). This means that the Bugis people's floating houses on the water will continue to apply the philosophy of life that has been believed for generations in their homes. Even with the disclosure of different forms of physical culture, due to adaptation to climatic conditions and physical conditions of the natural environment in Lake Tempe.

In addition, the architecture of the Bugis Tribe is considered "living architecture" because it is like the human body which consists of 3 parts, namely the head (roof), body (middle part as a place to live) and feet (under the house). For Bugis people, a house is a reflection of themselves (between husband and wife), so that it will create the value of the unity of family life. A human has a collarbone, at home it is called bate-bate (a kind of accessory that are located under the roof, on the left and right of the house. like earrings to women). The backbone in humans, at home is called aju lakke (The ridge beam on the roof, or the highest beam at the top of the gable roof). Feet in humans, at home called aliri (vertical pillars on the frame of the house). Humans have veins, at home called arateng (The beam that extends to the back is under the floor) or pattolo (beam that crosses sideways) or bare' (The beam that extends to the back is under the ceiling) (Data, 1977; Mardanas et al., 1985). This is what causes Bugis houses to always be in the form of houses on stilts, having a pillar/underground at the bottom of the house. Both houses built on land or houses float on water. The formation of space based on body size is also found in the Balinese house, who considers the universe to be divided into three worlds: the upper world, the middle world and the underworld. The layout of the house reflects this pattern (Waterson, 2002).

Based on taxonomic analysis, this floating house has the same shape as traditional mainland stilt houses. Where the floating house has a rectangular floor plan model and a saddle-shaped roof model, as is usually the case with mainland Bugis traditional houses. This similarity is also found in the building process, where the 
concept of building a floating house is strongly influenced by the cosmological view of the Bugis, who views the universe as a rectangular rhombus called sulapa eppa bola suji (rectangular shape). Where something is considered perfect if it has four squares. This philosophy is based on human events which consist of four elements, namely: earth, water, fire, and wind (Robinson, 2005).

The componential analysis found the cultural theme of using materials to build floating houses, where the materials used are natural materials that are easily available in the environment around the lake. The culture of using bamboo and wood in the construction of houses is a hallmark of the process of building floating houses on Lake Tempe. In addition to being cheaper, their use is also more flexible. Bamboo is the main material in making rafts, house floors and house walls. While wood is used as the mainframe pillars, floors, and walls. Bamboo and wood are materials that are adaptive to changes in the hot-cold climate on the surface of the water. This is in accordance with Ballantyne (2002) stated in (Octawati, et al., 2016) that tectonics is related to the nature of the material.

For vertical tectonics, the bottom structure of floating house (under) consists of a raft structure as the foundation and under the house with a pile height of $40-50 \mathrm{~cm}$ from the raft. Usually under the house at the front functioned as a place to keep chickens and the other bottom as a path of air circulation. This is intended so that air circulation from below remains smooth so that it can reduce the level of humidity on the floor and residential space above it. Tectonics The raft functions as a buoy and support structure for the bottom, where the raft is made of bamboo which is arranged crosswise. The tectonic appearance of the bottom of this floating house is different from the structure of the bottom of the lanting house in Kalimantan.

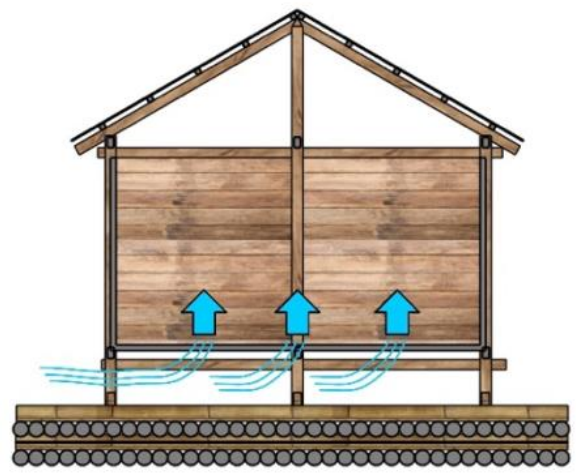

Figure 2. Tectonics at the Bottom of the Floating House and Air Circulation Space Sources: Personal Sketches, 2021

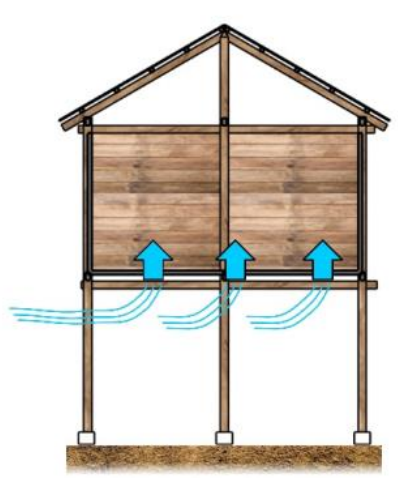

Figure 3. Tectonic Bottom of the House on Land Stilts for Air Circulation Source: Survey Results, 2009

Tectonics bodies floating house consists of structural floors, structural walls, and structural ceiling. The floor structure uses wood and bamboo which are arranged not tightly, so that the air at the bottom can rise to the top. In the middle structure (the body of the house) (Bugis: ale bola), it is used as a place to live and a place to carry 
out economic activities. While the upper structure (rakkeang) is only used as a place to put fishing equipment. Generally, all floating houses do not have a ceiling structure as a barrier between the space under the roof and the basement as a residence, so that the roof structure can be exposed. This is intended to reduce the volume of the house so that it does not sink. This condition is different as stated by Hamid (1986) that generally, mainland Bugis houses use ceilings, which function to store agricultural products such as rice, corn, or a place to store attoriolong (a set of ritual ceremonial equipment for the 'magical power' of certain objects). This is still related to the notion of syncretism which is still attached and believed in some of the interior Bugis people.

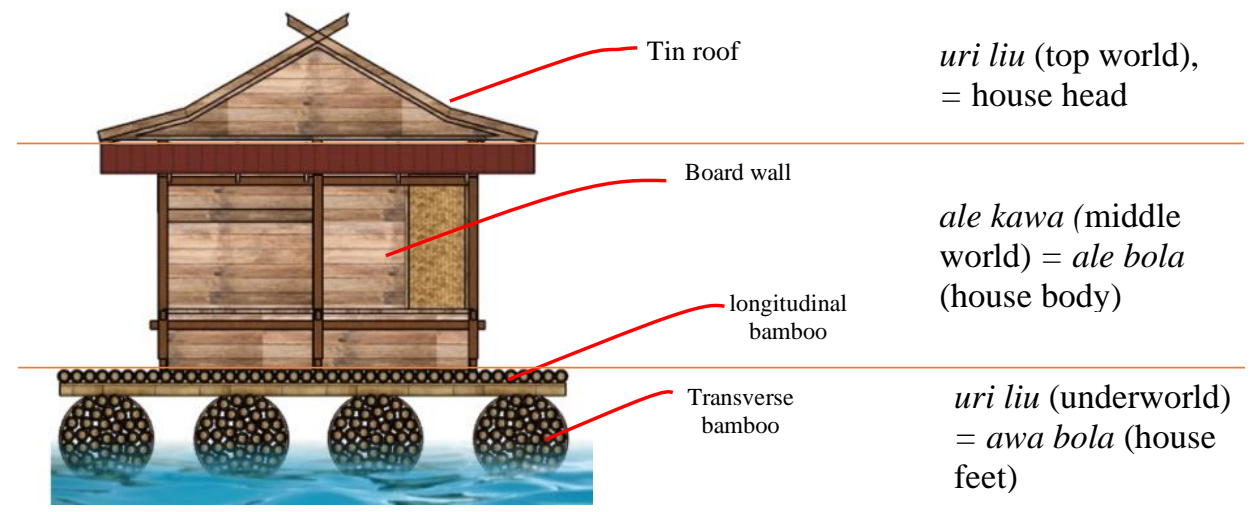

Figure 4. The Concept of Cosmological Understanding of

The Floating House

Source: Personal Sketch, 2021

Even though it is on the water, this floating house still refers to the concept of traditional Bugis architecture which was built with a ritual ceremony based on the habits of the Bugis tribe for generations. This ritual ceremony begins with looking for a good day to build a house, erecting the main pillar of the house (possi bola) as the center of the house, until the ritual of salvation enters a new floating house. This ritual is intended for the safety of the occupants of the house and smooth sustenance while occupying the house, because people in this area believe that, every house has a ruler of spirits (Naing \& Hadi, 2020).

The tectonics of floating houses based on the tradition of building on floating houses shows a structural arrangement that still reflects the cosmological understanding of the Bugis people in living on water, which is in accordance with cosmological understanding so that the house takes the form of a stage and the shape of a sulapa eppa (rectangular) and uses guidelines for the parts of the human body in its elements. frame construction elements. Although the structure of the bottom of the change in volume and mass of the composition of the bamboo rafts under the colonnaded combined with low but was shortly to create a structure different expression of the tradition of building homes Bugis people in general on the mainland. This integration of the lower part of the structure is still in accordance with the culture of the Bugis people. This is in line proposed by Frampton (1995) in Mochsen (2015) where the tectonic there are stages stereotomy in which the mass and volume of space formed from heavy elements in the form of processing link systems to the construction 
and structure that will enhance the expression of the building by presenting value art (Frampton, 1995 in Sir, 2015).

\section{Floating House Tectonics to Anticipate Disaster}

Based on the componential analysis, it shows that the community tradition of building stilt houses on land has differences in building settlements on water. The thing that distinguishes it is the use of house elements that are adapted to environmental conditions on the water, especially considerations for disaster mitigation on water which tend to be extreme. Although the climatic conditions above the lake water are not as extreme as the climate in the ocean, disaster mitigation has become a consideration in building houses (Ari \& Pradipto, 2020). The difference lies in the structure of the bottom of the house in the form of a raft of bamboo which serves as the foundation of the house. In detail, fishing communities on the water apply local wisdom in the construction of floating houses for disaster mitigation. Good in the application of the lower structure, the middle structure and the upper structure.

Meanwhile, based on taxonomic analysis, the structure of the floating house basically has similarities with the structure of the stilt house on the mainland in general. The difference lies in the structure of the bottom of the house in the form of a raft of bamboo which serves as the foundation of the house. In detail, fishing communities on the water apply local wisdom in the construction of floating houses for disaster mitigation. Good in the application of the lower structure, the middle structure, and the upper structure. The floating house consists of 3 main parts, namely: the bottom (raft and poles/under), the middle (house body, floor, walls), the top (ceiling/rakkeang and roof). The tectonics of this floating house has its own wisdom in mitigating disasters on water, so that life on water can continue.

The results of the componential analysis also found cultural themes in the division of space. Where the house on the mainland is quite complete including a living room, bedroom, kitchen, bathroom, family room. While the space in the floating house is only divided into 3 parts, namely the terrace, the core building, and the kitchen. The space at the core of the house is made without space barriers. This room is usually used as a place for all activities such as serving guests, sleeping, and chatting with family or commonly referred to as a multi-function room because the function of the room changes based on the activities carried out (Naing et al., 2011). The lack of space formed in the house floats because it is related to the security of living.

The interior layout system without partitions in the floating house is also made so that the existing load is not too heavy to burden the lower structure. Based on the local community knowledge system, this is intended so that the overall load of the house can be lighter, not easy to sink and can be moved around. This is based on the characteristics of the lake water that experiences ups and downs, so this raft house will be moved from one place to another above the water, based on the condition of the lake water level (Naing et al., 2011). Floating house tectonics will be analysed starting from raft construction tectonics, wall construction tectonics and roof construction tectonics, as below. 


\section{Raft Construction Tectonics}

The raft structure system in the floating house uses bamboo. This is different with other houses on the water that is in some places in Indonesia, or in some other country. The house floats in Kalimantan and Sumatra who use the structure of the wooden raft, in Vietnam using plastic drum, in Cambodia using drums of zinc, in San Francisco boat at the bottom of the house and also the Bajo (Naing et al., 2011).

The structure of the raft in the floating house uses bamboo which is stacked in three different layers. The first layer is bamboo which functions as a float so that the house can float on it. Several bamboos are tied together to form a large and strong bond. The number of bamboos in each bunch is 20-30 pieces of bamboo. Then the bamboo ties are lined up parallel and spaced according to the width of the body of the house, if there are enough bamboo ties available, then the bamboo ties are only spaced an inch apart, and if there is little bamboo, the bamboo ties are spaced $\pm 30-40$ $\mathrm{cm}$. According to interviews conducted, the arrangement of the bottom bamboo in large quantities tied into one piece is the result of experience and habits of building rafts that have been carried out for generations based on experience in anticipating the natural conditions that exist in the lake environment. This is intended so that this bamboo bond can be the main support for the house above it to be able to withstand the burden of the house so that it does not sink easily due to the heavy load on it.

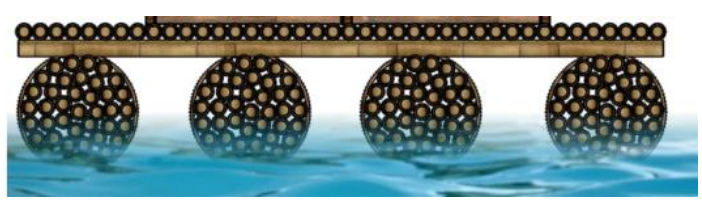

Figure 5 . Cross Section of Raft Structure Source: Personal Sketch, 2021

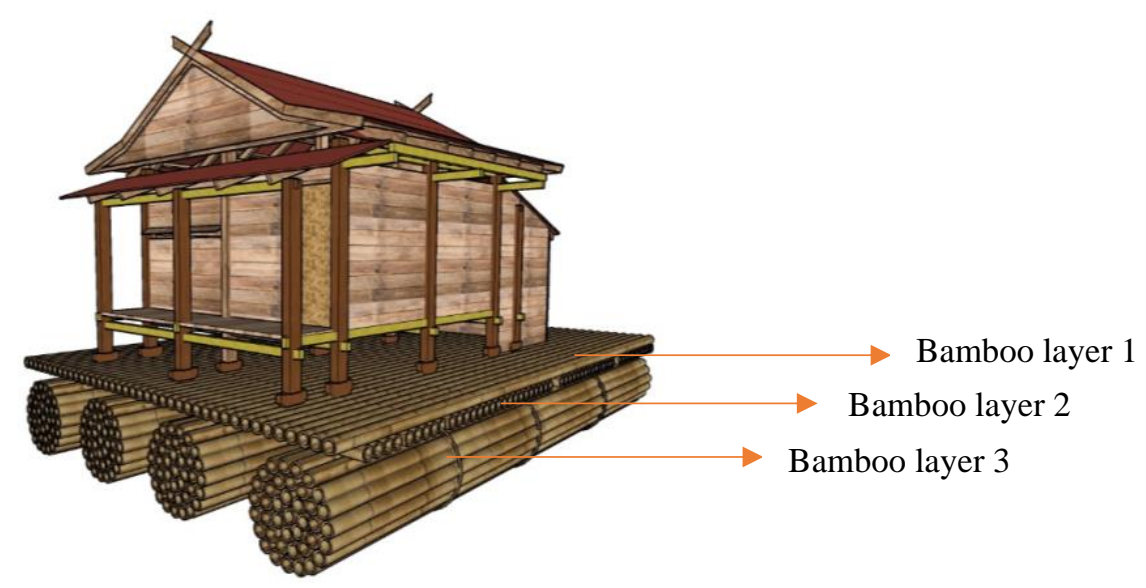

Figure 6 . Raft Structure Top View Source: Personal Sketch, 2021 


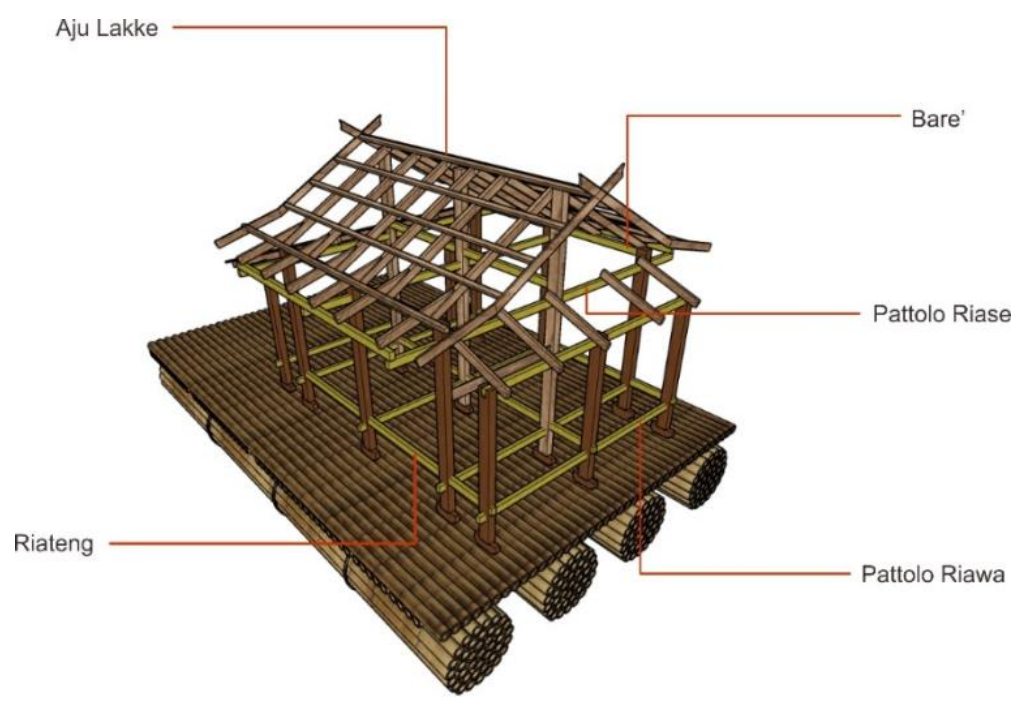

Figure 7. Pieces of Floating House Under Structure System Source: Personal Sketch, 2021

Another part of the substructure apart from the raft is the lower pile structure. To connect the structure of the poles, the poles are tied by pattolo riawa (The lower beam that crosses to the side) beams at the bottom of the floor which is placed horizontally transversely and longitudinally using dowel connections. In addition, there are also Arateng (the lower beam that extends backwards is under the floor), namely flat beams measuring $3 \mathrm{~cm}$ x $10 \mathrm{~cm}$ which are also placed in 90 degrees different directions from the pattolo riawa beam. The two beams under the floor serve as a place to stand from shocks, or wind blows.

To connect the pillars of the house to the raft foundation, shoe pads are given in the form of a $3 / 10$ wooden block with a length of $\pm 45 \mathrm{~cm}$. wooden shoe mats are installed horizontally on the second layer of bamboo rafts and then connected to the floor support posts by means of notches.

\section{Wall Construction Tectonics}

The wall construction of the floating house consists of wood and bamboo construction with an arrangement and bonding system in accordance with the traditions of the Bugis community. The wall construction has a tiered wall model and a spaced wall. According to local people, these two types can anticipate high wind disasters on the water surface. The type of tiered wall consists of boards that are mounted horizontally on the pillars of the walls of the house with a distance of $\pm 1 \mathrm{~cm}$ between the boards and the fifth and sixth boards are spaced $\pm 15 \mathrm{~cm}$ apart as shown in Figure 10. The height of the walls is usually $250 \mathrm{~cm}$ which is installed horizontally. Between the arrangement of the boards as wall coverings, vents are usually placed as windows or gaps where the wind enters the house to float. According to the local community, this is intended so that the house is not too heavy, thereby reducing the load from the 
bottom raft, so that it is not easily fragile and detached due to too heavy a load from the house above it, if blown by strong winds.
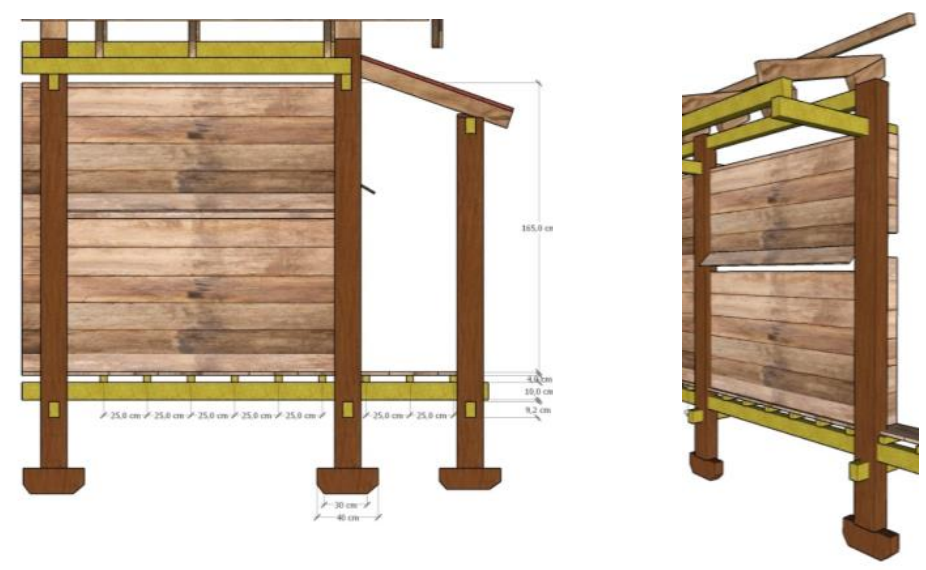

Figure 8. Construction Details of Type 1 Board Walls on the Front and Side Source: Personal Sketch, 2021

The second type is a board that is installed horizontally on the pillars of the walls of the house with a slope of $\pm 5^{\circ}$ to the other boards. In the order of the fifth board from the floor, a distance of $\pm 10 \mathrm{~cm}$ is given between the fifth and sixth boards. On the front wall of the house, the board is fully installed but the fifth board is added with hinges so that it can be opened at any time and can function as a house window. The spacing of the wallboards serves as a cavity to channel air, in addition to changing air (healthy house standards) but also as a windbreaker in the event of a strong enough wind so that the house floats not blown away by the wind and only moves around the mooring pole of the house.
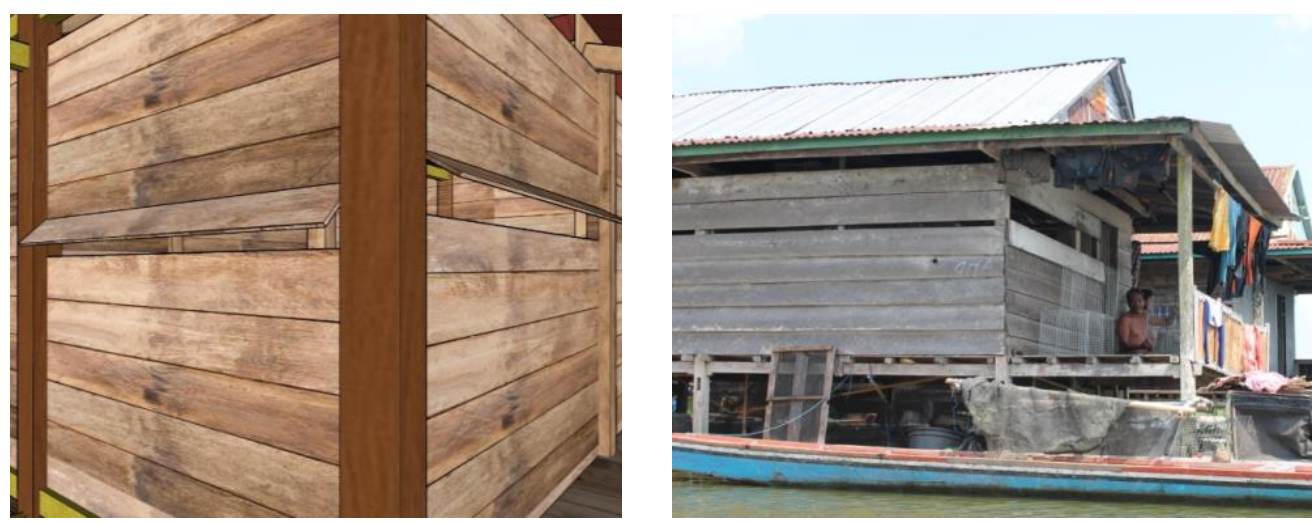

Figure 9. Type 2 Board Wall Construction Details on the Front and Side Source: Personal Photos \& Sketches, 2021 


\section{Roof Construction Tectonics}

The basic principle of roof construction on floating houses is that the roof becomes a building blanket or building cover, which functions to withstand heat and cold from the outside environment of the building, especially for humid tropics. The construction of the floating roof of the house is made of wood because wood has a lightweight nature, thereby reducing the burden on the roof construction. In addition, wood is easy to obtain, easy to transport, and can be done with simple machines and tools. The use of a complete wooden truss system such as on stilt houses on the mainland is considered less effective because it will increase the volume of the floating house as a whole. For this reason, the volume of construction material in the floating house is reduced by using a roof truss construction system that is slightly different from the horses in general so that the roof load is reduced.

The construction of the truss on the roof is made by assembling several logs measuring $6 \mathrm{~cm} \times 12 \mathrm{~cm}$ which are formed into a truss construction with a triangular base shape. The truss component of the floating house consists of truss legs, curtains, roof ridge beams, and overhang. The legs of the horses form the angle of the roof slope, which serves as a support for the curtain beam. Curtain block serves as the foundation of the roof covering material. The roof ridge beam is mounted on the top end of the main pillar as a place to support the ends of the truss beams.

The principle of roof structure construction on floating houses, in addition to covering the building according to the tradition of building the community, for the aesthetics of the house, also for disaster mitigation with lightweight and climateresponsive materials. Light materials are used with the intention that the load from the roof, which is passed on to the pillars and beams of the house frame, is not too burdensome. This is intended so that the volume of the house becomes lighter, and the house can rotate on the pole during strong winds, so that the floating house has resistance to strong wind disasters on the water. In addition, the roof structure of the floating house is not equipped with a ceiling, so that the roof truss construction remains exposed, showing the connection and material.
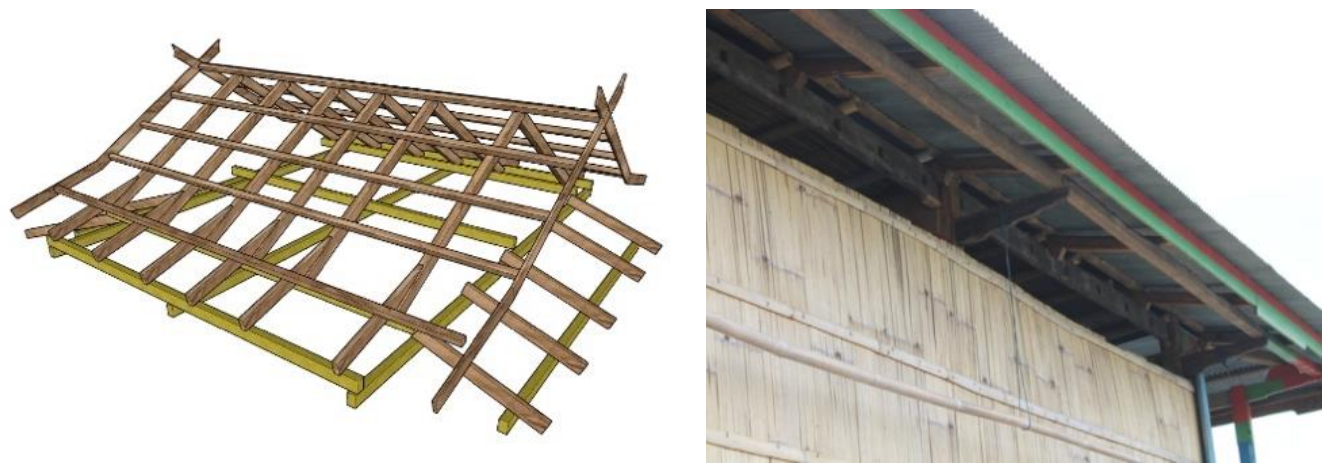

Figure 10. The Roof Tectonics of the Floating House is Lightly

Exposed without a Ceiling. On the Front and Side Source: Personal Photos \& Sketches, 2021 


\section{CONCLUSION}

The tectonic form of the floating houses on Lake Tempe, based on the tradition of building the Bugis tribal community. This is manifested in the structural arrangement that still reflects the cosmological understanding of the Bugis people in living on the water, namely the structure of the house on stilts which reflects the 3 natures and the form of sulapa eppa. In addition, it uses guidelines for the parts of the human body in the elements of its skeletal construction. However, the lower structure has changed with the addition of a mass of bamboo rafts so that the house can float. From the results of the componential analysis found a cultural theme where the volume of the floating house mass is made lighter by simplifying the structure starting from the roof structure, wall structure, floor structure, the volume of the house as a whole does not burden the raft structure. This creates a tectonic form of floating houses for the survival of living on water. Where such a structural model is intended so that the house can move more flexibly to the rhythm of the strong winds so that the house is easy to move on the axis and is lighter to move from one place to another on the water. Reducing the height of the substructure so that the house is not easily overturned by strong winds, so that in general, the floating house structure is proven to have disaster resistance on water but has created a different art of structural beauty and is the only one in this world.

\section{REFERENCES}

Ari, A. S., \& Pradipto, E. (2020). Tektonika Rumah Sasadu sebagai Struktur Konstruksi yang Ramah Gempa. 033-040. https://doi.org/10.32315/sem.4.033. Prosiding Seminar Struktur Dalam Arsitektur. ISBN 9786239323226. Penerbit Institut Teknologi Bandung.

Data, Yamin (1977), Bentuk-bentuk Rumah Bugis Makassar. Penerbit Proyek Pengembangan Media Kebudayaan Direktorat Jenderal Kebudayaan Departemen Pendidikan dan Kebudayaan RI. Makassar.

Hamid, Abu, dkk. (1986), Pertumbuhan Permukiman Masyarakat di Lingkungan Perairan Daerah Sulawesi Selata. Departemen Pendidikan dan Kebudayaan Direktorat Jenderal Kebudayaan, Proyek Inventarisasi dan Dokumentasi Kebudayaan Daerah Sulawesi Selatan. Jakarta.

Juniawati, Anik (2003). Perlunya Pengetahuan Tektonika Pada Pengajaran Struktur di Arsitektur. Jurnal Dimensi Teknik Arsitektur Vol. 31 No. 2, Jurusan Teknik Arsitektur, Fakultas Teknik Sipil dan Perencanaan-Universitas Kristen Petra Surabaya.

Kamurahan, S. R. (2018). Struktur Dan Konstruksi Rumah Panggung Masyarakat Kampung Jawa Tondano (Jaton) Ditinjau Dari Prinsip-Prinsip Bangunan Tahan Gempa. Media Matrasain, 15(1), 1-8. Penerbit: Universitas Sam ratulangi Manado.

Mardanas, Izarwisma, dkk. (1985), Arsitektur Tradisional Daerah Sulawesi Selatan, Departemen Pendidikan dan Kebudayaan Direktorat Jenderal Kebudayaan, 
Proyek Inventarisasi dan Dokumentasi Kebudayaan Daerah Sulawesi Selatan. Makassar

Meutia, E. (2017). Pemetaan Sistem Struktur Konstruksi Rumah Tradisional Aceh Dalam Merespon Gempa. Jurnal Koridor, 8(1), 65-72. https://doi.org/10.32734/koridor.v8i1.1330. Penerbit :Univesitas Sumatera Utara.

Naing, N., \& Hadi, K. (2020). Vernacular Architecture of Buginese: The Concept of Local Wisdom Constructing Buildings Based on Human Anatomy. Journal International Review for Spatial Planning and Sustainable Development, 8(3), 1-15. https://doi.org/10.14246/irspsd.8.3_1.ISSN 21873666. Japan.

Naing, N., \& Halim, H. (2013). Sistem Struktur Rumah Mengapung di Danau Tempe Sulawesi Selatan. Jurnal Permukiman, 8(3), 145-152. Penerbit : Pusat Litbang Perumahan dan Permukiman. Bandung

Naing, N., \& Iskandar, B. P. (2015). Model of Settlements Float Management Based on Local Wisdom For Disaster Mitigation In Tempe Lake - Indonesia. International Journal of Applied Engineering Research, 10(21), 42329-42335.

Naing, N., Santosa, H. R., \& Soemarno, I. (2011). Living on the Floating Houses for Sustainable Livelihoods at Lake Tempe, South Sulawesi. Journal Environment and Urbanization Asia, 2(1), 93-108. https://doi.org/10.1177/097542531000200107

Oktawati, A. E., \& Sahabuddin, W. (2016). Karakter Tektonika Rumah Tongkonan Toraja. Prosiding Seminar Nasional Semesta Arsitektur Arsitektur Nusantara 4 , Kebangsaan, (November), 17-18. Universitas Islam Negeri, Makassar.

Priyomarsono, N. W., \& Surya, R. (2016). Aspek Tektonika Menjawab Arsitektur Masa Kini. Prosiding Seminar Nasional Avoer 8, Applicable Innovation of Engineerng and Science Researches. Palembang Indonesia.

Rahmansah, \& Rauf, B. (2014). ARSITEKTUR TRADISIONAL BUGIS MAKASSAR (Survei pada Atap Bangunan Kantor di Kota Makassar). 12. JurnalForum Bangunan. Penerbit: Universitas Negeri Makassar.

Rembulan, L., Hardiyati, \& Mutaqimah, U. (2014). Penerapan Tektonika Arsitektur YB. Mangunwijaya Dalam Perancangan Rumah Tinggal Emha Ainun Nadjib. Jurnal Arsitektura Vol. 12 No. 1, Penerbit : Universitas Sebelas Maret, Surakarta.

Robinson, Kathryn, dkk. (2005), Tapak Tapak Waktu, Kebudayaan, Sejarah, dan Kehidupan Sosial di Sulawesi Selatan, Penerbit Ininnawa, Makassar.

Sir, M. M. (2015). Pengetahuan Tektonika Arsitektur Tongkonan. Seminar Nasionan Dan Loka Karya Nasonal Pemahaman Sejarah Arsitektur (LPNSA) XI-2015, 114. Penerbit : Universitas Wahid Hasyim, Semarang-Jawa Tengah.

Spradley, James P (1980), Participant Observation, Holt, Rinehart and Winston, New York.

Spradley, James P (2006), Metode Etnografi, Penerbit Tiara Wacana, Yogyakarta.

Waterson, Roxana (2002), Rumah Tinggal dalam Manusia dan Lingkungan, Penerbit Grolier International, Jakarta. 
Naing: FLOATING HOUSES TECTONIC ON LAKE TEMPE: BETWEEN TRADITION AND RESILIENCE

This Page is Intentionally Left Blank 